\title{
Effects of trivalent chromium on biomass growth, water use efficiency and distribution of nutrient ele- ments in rice seedlings
}

\author{
Xiao-Zhang Yu ${ }^{1,2^{*}}$ and Xing-Hui Feng ${ }^{1}$ \\ ${ }^{1}$ The Guangxi Key Laboratory of Theory and Technology for Environmental Pollution Control, College of Environ- \\ mental Science \& Engineering, Guilin University of Technology, Guangxi 541004, People’s Republic of China \\ ${ }^{2}$ Collaborative Innovation Center for Water Pollution Control and Water Safety in Karst Area, Guilin University of \\ Technology, Guilin 541004, People’s Republic of China
}

\begin{abstract}
This paper presents an investigation of the effects of trivalent chromium on biomass growth (RGR), water use efficiency (WUE) and distribution of nutrient elements in young rice seedlings (Oryza sativa L. cv. XZX 45) exposed to chromium nitrate ( $\mathrm{Cr}(\mathrm{III})$ ) hydroponically. Results indicated that phytotoxicity of $\mathrm{Cr}(\mathrm{III})$ to rice seedlings was apparent, showing an linear decrease in both RGR and WUE with increasing $\mathrm{Cr}$ (III) concentrations. Using the Levenberg-Marquardt Algorithm, the effective concentrations (EC) obtained from the RGR were always smaller than these from WUE, indicating that the former was more sensitive to change of $\operatorname{Cr}(\mathrm{III})$ application than the latter. Although a dose-dependent total accumulation rate of $\mathrm{Cr}$ in plant materials was observed, the translocation of $\mathrm{Cr}$ into shoots was a restricted process during phyto-transport of $\mathrm{Cr}$ within plant materials. Results also showed that the effect of $\mathrm{Cr}(\mathrm{III})$ application on uptake and distribution of nutrient elements in rice seedlings was variable. In conclusion, the toxic response of young rice seedlings to $\mathrm{Cr}(\mathrm{III})$ was obvious and inhibitory effects were highly dependent on the total accumulation rate of $\mathrm{Cr}$ in plant materials.
\end{abstract}

Keywords: accumulations, effective concentration, nutrient elements, phytotoxicity, rice seedlings

*Correspondence to: Xiao-Zhang Yu, The Guangxi Key Laboratory of Theory and Technology for Environmental Pollution Control, College of Environmental Science \& Engineering, Guilin University of Technology, Guangxi 541004, People’s Republic of China; Email: yuxiaozhang@hotmail.com

Received: October 6, 2015; Accepted: January 20, 2016; Published Online: April 8, 2016

Citation: Yu X-Z and Feng X-H, 2016, Effects of trivalent chromium on biomass growth, water use efficiency and distribution of nutrient elements in rice seedlings. Applied Environmental Biotechnology, vol.1(1): 64-70. http://dx.doi.org/10.26789/AEB.2016.01.005.

\section{Introduction}

$\mathrm{D}$ uring the past three decades, the rapid economic development and lack of environmental awareness has resulted in the contamination of a significant number of agricultural sites with heavy metals in mainland China ${ }^{[1]}$. Chromium (Cr) is one of most commonly found heavy metals in the environment. Indeed, it is estimated that cumulative Cr pro- duction was approximately 105.4 million tons globally in $2000^{[2]}$. Naturally, $\mathrm{Cr}(\mathrm{VI})$ and $\mathrm{Cr}(\mathrm{III})$ are the most common and stable species in the family of Cr. Both compounds are toxic, but remarkable difference in chemical properties, occurrence, behavior, and biological effects has been reported ${ }^{[3]}$. Therefore, the recommended guideline is $1 \mathrm{~g} \mathrm{Cr}(\mathrm{VI}) / \mathrm{L}$ and $8 \mathrm{~g} \mathrm{Cr}(\mathrm{III}) / \mathrm{L}$ for freshwater life, and $1 \mu \mathrm{g} \operatorname{Cr}(\mathrm{VI}) / \mathrm{L}$ and $50 \mu \mathrm{g} \mathrm{Cr}(\mathrm{III}) / \mathrm{L}$ for marine life $\mathrm{e}^{[4]}$.

Effects of trivalent chromium on biomass growth, water use efficiency and distribution of nutrient elements in rice seedlings. (C) 2016 Xiao-Zhang Yu and Xing-Hui Feng. This is an Open Access article distributed under the terms of the Creative Commons Attribution-NonCommercial 4.0 International License (http://creativecommons.org/licenses/by- nc/4.0/), permitting all non-commercial use, distribution, and reproduction in any medium, provided the original work is properly cited. 
The toxicity of $\mathrm{Cr}$ to animals and humans is well documented. It has been established that $\mathrm{Cr}(\mathrm{VI})$ is carcinogenic and mutagenic to animals and humans ${ }^{[5]}$, while $\mathrm{Cr}$ (III) at low concentrations is considered to be a trace element essential for the proper functioning of living organisms ${ }^{[6]}$. It is well known that excessive $\mathrm{Cr}$ can interfere with several metabolic and biochemical processes in plants, resulting in inhibition of seed germination and plant growth, impairment of nutrient balance and water relations, degradation of photosynthetic pigments, and reduction of mitochondrial electron transport and activities of antioxidant enzymes ${ }^{[3,5,7,8]}$. Although there are abundant literatures describing phytotoxicity of $\mathrm{Cr}(\mathrm{VI})$, relatively little is known about phyto-responses to $\mathrm{Cr}(\mathrm{III})$. Additionally, numerous reports have been focused on the selection of hyperaccumulator species of plants, which mainly belong to grasses. Ample evidence showed that cultivated species may serve as a heavy metal receptor for accumulation. Rice is a global staple food, second only to wheat in its importance as a food cereal in the human diet, especially in Asia ${ }^{[9]}$. In this study, we measured several variables including biomass growth, water use efficiency and distribution of nutrient elements in order to provide more detailed information on phytotoxicity and transport of a trivalent cation in young rice seedlings exposed to chromium nitrate ranging from $2.0 \mathrm{mg} / \mathrm{L}$ (environmentally relevant) to $40.0 \mathrm{mg} / \mathrm{L}$ (high concentration).

\section{Materials and Methods}

\subsection{Test Chemicals and Experiment Design}

Fifteen-day-old rice seedlings (Oryza sativa L. cv. XZX 45) with similar height and weight were transplanted to a pre-treatment solution containing $1 \mathrm{mM}$ $\mathrm{CaCl}_{2}+2 \mathrm{mM}$ MES-Tris buffer ( $\mathrm{pH}$ 6.0) for 4 hrs to clear the ions from cell wall space ${ }^{[10]}$, and then ten rice seedlings were transferred into a $50 \mathrm{~mL}$ Erlenmeyer flask filled with $50 \mathrm{~mL}$ modified ISO 8692 nutrient solution $^{[11]}$ with addition of $10 \mu \mathrm{M}$ Fe-EDTA, but without $\mathrm{NaHCO}_{3}$. The plants were first conditioned for 24 hrs to allow adaptation to the new environmental conditions. The flasks were all wrapped with aluminum foil up to the flask mouth to prevent escape of water, and to inhibit potential growth of algae inside. All flasks were housed in a plant growth chamber with constant temperature of $25 \pm 0.5^{\circ} \mathrm{C}$ and a relative humidity of $60 \pm 2 \%$ under continuous artificial light. Then, the nutrient solution in each flask was replaced by spiked solution, except for the controls.

Chromium nitrate $\left(\mathrm{Cr}\left(\mathrm{NO}_{3}\right)_{3} \cdot 9 \mathrm{H}_{2} \mathrm{O}\right.$, CAS No.778902-8, 99.5\% purity) were purchased from Sinopharm Chemical Reagent Co. Ltd., Shanghai, PR China. Eight different concentrations were used. Nominal concentrations of $\mathrm{Cr}$ in treatments spiked with $\mathrm{Cr}\left(\mathrm{NO}_{3}\right)_{3}$. $9 \mathrm{H}_{2} \mathrm{O}: 0,2.0,4.0,8.0,16.0,24.0,32.0,40.0 \mathrm{mg} \mathrm{Cr} / \mathrm{L}$. Each treatment concentration was conducted in four independent biological replicates. Two testing series (48-hr and 96-hr exposure period) were conducted.

\subsection{Chemical Analysis}

Treated and non-treated rice seedlings were collected at the termination of experiments, rinsed with deionized water and divided into roots and shoots. Different parts of plant tissues were dried at $90^{\circ} \mathrm{C}$ for $48 \mathrm{hrs}$ and mixed with $10 \mathrm{~mL}$ of $4: 1 \mathrm{HNO}_{3}-\mathrm{HClO}_{4}$ solution for overnight. Then, samples were placed in a digestion block and heated for 2 hrs at $200^{\circ} \mathrm{C}$ until the digested liquid was clear. The cooled residue was dissolved in $0.2 \mathrm{~mL}$ of $1 \% \mathrm{HNO}_{3}$ and deionized water was added up to $50 \mathrm{~mL}$ of total volume ${ }^{[12]}$. The content of total $\mathrm{Cr}$ and other nutrient elements $(\mathrm{K}, \mathrm{Na}, \mathrm{Ca}$, $\mathrm{Mg}, \mathrm{Cu}, \mathrm{Fe}, \mathrm{Mn}$ and $\mathrm{Zn}$ ) in plant materials was all analyzed by inductively-coupled plasma atomic emission spectrometry (ICP-AES).

\subsection{Determination of Relative Growth Rate and Water Use Efficiency}

Relative growth rate (RGR) and water use efficiency (WUE) of rice seedlings were quantified via measuring the weight prior to application and at termination of exposure, and water transpired by plants as previously described $^{[13]}$.

\subsection{Inhibition Rate}

Percent inhibition rate (IR, \%) on each parameter was calculated using the equation ${ }^{[14]}$

$$
I R_{(C, t)}=\left(1-\frac{\frac{1}{n} \sum_{i=1}^{n} \mu_{(C, t)}}{\frac{1}{m} \sum_{j=1}^{m} \mu_{(O, t)}}\right) \times 100
$$

Where $C$ is concentration (mg $\mathrm{Cr} / \mathrm{L}$ ), $t$ is time period (d), $\mu$ is different measured parameter, $i$ is replicate 1 , $2, \ldots, n$ and $j$ is control $1,2, \ldots, m$.

\subsection{Effective Concentration}

The EC values at the respective time intervals were 
estimated by Levenberg-Marquardt Algorithm with 95\% confidence intervals using Logistic Model of Origin v. 9.0, which is a commonly used program designed for logistic dose response in Chemistry.

$$
f(x)=A_{2}+\frac{A_{1}-A_{2}}{1+\left(\frac{x}{x_{0}}\right)^{P}}
$$

Where $A_{1}$ is the initial value, $A_{2}$ is the final value, $X_{0}$ is the central value for EC of the dose-response curve, and $P$ is the slope of dose-response curve; $f(x)$ is the function of chemical concentration $x$, here it refers to percent inhibition rate for each selected parameter.

\subsection{Total Accumulation Rate}

The total Cr accumulation rate (TAR, $\mu$ g Cr/g DW.d) was calculated from final mass accumulated in different parts of plant materials using the formula ${ }^{[15]}$ with slight modification

$$
T A R=\frac{C_{(\text {shoot })} \cdot D W_{(\text {shoot })}+C_{(\text {root })} \cdot D W_{(\text {shoot })}}{\left(D W_{(\text {shoot })}+D W_{(\text {root })}\right) \cdot \Delta t}
$$

Where $C_{(\text {shoot })}$ and $C_{(\text {root })}$ are the total Cr concentration in different plant materials and $D W_{\text {(shoot) }}$ and $D W_{\text {(root) }}$ are the dry weight production of plant materials. $\Delta t$ is the time period of exposure (d).

\subsection{Statistical Method}

The experiments in this study were repeated four times and the data shown are the means \pm SEs. One single factor ANOVA test and Tukey's multiple comparison tests were used to determine the statistical significance at the 0.05 level between $\mathrm{Cr}$ treatment and control.

\section{Results}

\subsection{Effects of $\mathrm{Cr}$ (III) on Biomass Growth and Water Use Efficiency}

Phytotoxicity of $\mathrm{Cr}(\mathrm{III})$ to young rice seedlings was obvious (Table 1), after measuring the relative growth rate (RGR) and water use efficiency (WUE). Indeed, a linear decrease in RGR was observed with increasing Cr concentrations $\left(R^{2}=0.935, n=8\right)$ after 2-d incubation. Compared with non-treated plants, a significant reduction in RGR was detected with rice seedlings exposed to $\mathrm{Cr}$ at $4.0 \mathrm{mg} \mathrm{Cr} / \mathrm{L}$ onwards $(p<0.05)$, but all seedlings showed positive growth after 2-d exposure. All Cr treatments caused more remarkable effects on RGR was observed at the 4-d treatments $(p<0.05)$ with respect to control. The change of RGR also showed a negative linear correlation $\left(R^{2}=0.932\right.$, $n=8$ ).

In comparison to control, WUE in Cr-treated rice seedlings also displayed a dose-dependent decrease at the 2-d treatment $\left(R^{2}=0.978, n=8\right)$ and the 4-d treatment $\left(R^{2}=0.976, n=8\right)$. Decrease in WUE was all significant at higher than or equal to $8.0 \mathrm{mg} \mathrm{Cr} / \mathrm{L}$ $(p<0.05)$.

\subsection{Determination of Effective Concentrations of Cr(III) to Rice Seedlings}

The effective concentration (EC) is defined by the concentration of a chemical, which produces percentage inhibition of the maximum possible response for that chemical ${ }^{[16]}$. The inhibitory rate (\%), as measured by different variables at different incubation periods are shown in Table 2. It is quite clear that higher levels of $\mathrm{Cr}(\mathrm{III})$ resulted in more severe inhibition rates on both parameters. For instance, the increased inhibitory rates ranged between $13.26 \%$ and $70.88 \%$ in response to $\mathrm{Cr}$ treatments (2.0 to $40.0 \mathrm{mg} \mathrm{Cr} / \mathrm{L}$ ) after 2-d exposure, with respect to control. Additionally, the inhibitory effect was dependent on duration of incubation periods. Indeed, higher inhibition rates of both RGR and WUE were observed at the treatments of 4-d exposure. It is also noted that the inhibitory rates between the two selected variables were found to be different, in which Cr(III) always caused less inhibitory

Table 1. Effects of $\mathrm{Cr}(\mathrm{III})$ concentrations (mg Cr/L) on relative growth rate (RGR, \%) and water use efficiency (WUE, mg biomass/mL water transpired) of rice seedlings. Values are mean of 4 independent biological replicates. Numerical values in brackets

\begin{tabular}{|c|c|c|c|c|c|c|c|c|c|}
\hline Con & $\mathrm{r} / \mathrm{L})$ & 0 & 2.0 & 4.0 & 8.0 & 16.0 & 24.0 & 32.0 & 40.0 \\
\hline \multirow{4}{*}{ RGR } & \multirow{2}{*}{ 48-hr } & 23.82 & 20.66 & $19.24^{*}$ & $16.25^{*}$ & $13.46^{*}$ & $10.02^{*}$ & $8.20^{*}$ & $6.94^{*}$ \\
\hline & & (1.91) & $(0.63)$ & $(0.83)$ & (1.74) & (1.10) & (1.57) & (1.04) & $(1.70)$ \\
\hline & \multirow{2}{*}{ 96-hr } & 46.84 & $37.94^{*}$ & $34.89^{*}$ & $28.94^{*}$ & $21.86^{*}$ & $16.73^{*}$ & $10.28^{*}$ & $7.38^{*}$ \\
\hline & & (1.40) & (1.39) & (2.89) & $(0.94)$ & (1.77) & $(1.10)$ & $(0.21)$ & $(1.06)$ \\
\hline \multirow{3}{*}{ WUE } & \multirow{2}{*}{ 48-hr } & 44.45 & 40.40 & 38.52 & $33.91^{*}$ & $29.89^{*}$ & $24.44^{*}$ & $19.63^{*}$ & $15.66^{*}$ \\
\hline & & (3.21) & $(4.28)$ & (3.45) & (4.04) & (3.48) & (3.89) & (4.38) & (3.12) \\
\hline & 96-hr & (4.53) & (3.67) & (2.74) & (1.44) & (2.36) & $(0.69)$ & (2.33) & $(2.14)$ \\
\hline
\end{tabular}
represent standard deviation. Asterisk symbol refers to significance difference between Cr treatment and control $(p<0.05)$ 
Table 2. Inhibition rate (\%) of relative growth rate (RGR, \%) and water use efficiency (WUE, mg biomass $/ \mathrm{mL}$ water transpired) of rice seedling exposed to $\mathrm{Cr}(\mathrm{III})$. Values are mean of 4 independent biological replicates

\begin{tabular}{rcrrrrrrrr}
\hline \multicolumn{2}{c}{ Conc. (mg Cr/L) } & 0 & 2.0 & 4.0 & 8.0 & 16.0 & 24.0 & 32.0 & 40.0 \\
\hline \multirow{2}{*}{ RGR } & $48-\mathrm{hr}$ & 0 & 13.26 & 19.23 & 31.79 & 43.51 & 57.95 & 65.60 & 70.88 \\
& $96-\mathrm{hr}$ & 0 & 19.00 & 25.51 & 38.21 & 53.32 & 64.27 & 78.05 & 84.25 \\
\multirow{2}{*}{ WUE } & $48-\mathrm{hr}$ & 0 & 9.12 & 13.34 & 23.71 & 32.75 & 45.01 & 55.85 & 64.77 \\
& $96-\mathrm{hr}$ & 0 & 10.08 & 15.06 & 24.51 & 37.74 & 47.02 & 58.53 & 69.47 \\
\hline
\end{tabular}

effects on WUE than RGR in all treatments.

In this study, the $\mathrm{EC}_{10}, \mathrm{EC}_{20}$ and $\mathrm{EC}_{50}$ correspond to the dose, at which the selected parameters are inhibited at $10 \%, 20 \%$ and $50 \%$ respectively ${ }^{[13]}$. Using non-linear regression, the Levenberg-Marquardt Algorithm was performed to calculate EC values. The simulation curves of concentration-response model shown in Figure 1A and 1B indicated that all trends yielded were significant, judged by the critical $R$ for
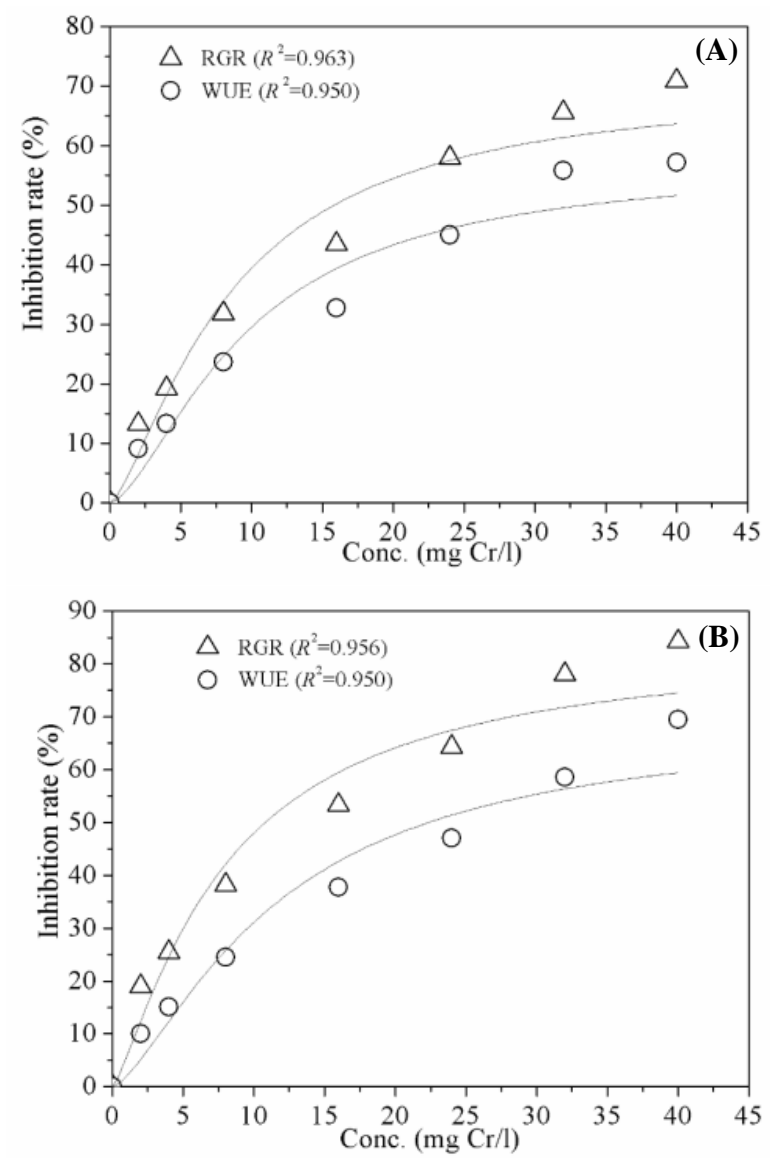

Figure 1. Simulation curves of inhibition rates of various parameters of rice seedlings exposed to different $\mathrm{Cr}(\mathrm{III})$ concentrations at different exposure periods; (A): 2-d, (B): 4-d; RGR: relative growth rate, WUE: water use efficiency; Values are mean of 4 independent biological replicates).
Table 3. Estimation of the ECs of Cr(III) to rice seedlings using different response endpoints

\begin{tabular}{llllllllll}
\hline \multirow{2}{*}{ Chemicals } & \multicolumn{3}{c}{ RGR } & & \multicolumn{3}{c}{ WUE } \\
\cline { 2 - 4 } \cline { 8 - 9 } & & $\mathrm{EC}_{10}$ & $\mathrm{EC}_{20}$ & $\mathrm{EC}_{50}$ & & $\mathrm{EC}_{10}$ & $\mathrm{EC}_{20}$ & $\mathrm{EC}_{50}$ \\
\hline \multirow{2}{*}{$\mathrm{Cr}(\mathrm{mg} \mathrm{Cr} / \mathrm{L})$} & $48-\mathrm{hr}$ & 2.35 & 4.38 & 15.81 & & 3.69 & 6.78 & 26.80 \\
& $96-\mathrm{hr}$ & 1.64 & 3.18 & 10.79 & & 3.33 & 6.15 & 22.35 \\
\hline
\end{tabular}

given $n(\alpha=0.05)$. Therefore, the EC values for different parameters at the respective time interval can be estimated using the fitting equations (Table 3). It is of interest to note that all EC values based on RGR were smaller than those on WUE, suggesting that RGR of rice seedlings is more sensitive to $\mathrm{Cr}(\mathrm{III})$ exposure than WUE.

\subsection{Accumulation of $\mathrm{Cr}$ in Different Parts of Rice Seedlings}

After exposure to $\mathrm{Cr}(\mathrm{III})$, total $\mathrm{Cr}$ content in plant materials of rice seedlings were measured (Table 4). Cr content in roots and shoots of non-treated rice seedlings was all below the detection limit, while significant amounts of Cr was found in both plant materials of $\mathrm{Cr}(\mathrm{III})$-treated plants, indicating transport of $\mathrm{Cr}$ from hydroponic solution into plants and within plant materials. The total $\mathrm{Cr}$ content in both roots and shoots responded biphasically to $\mathrm{Cr}$ (III) treatment by showing linear increase at low $(2.0-24.0 \mathrm{mg} \mathrm{Cr} / \mathrm{L})$ (root: $y=60.12 x+449.05, R^{2}=0.865$; shoot: $y=8.95 x^{+}$ $\left.26.65, R^{2}=0.979\right)$ and almost constants at high (24.0$40.0 \mathrm{mg} \mathrm{Cr} / \mathrm{L}$ ) concentrations for the 2-d treatment (root: mean 1816.19, SD 42.67; shoot: mean 232.65, SD 2.88). It is interesting to note that a slightly different result was obtained in the 4 -d treatment. A positive linear correlation $\left(R^{2}=0.963\right)$ with dose-dependent $\mathrm{Cr}$ content in roots was observed at $2.0-24.0 \mathrm{mg} \mathrm{Cr} / \mathrm{L}$ of $\mathrm{Cr}(\mathrm{III})$ treatments, while a linear decrease in $\mathrm{Cr}$ content in roots was evident at $24.0 \mathrm{mg} \mathrm{Cr} / \mathrm{L}$ onwards. A similar pattern in Cr content was also observed in shoots after 4 d-exposure.

\subsection{Effects of $\mathrm{Cr}$ (III) on Distribution of Nutrient Elements}

The distribution of nutrient elements in rice seedlings exposed to $\mathrm{Cr}(\mathrm{III})$ was variable. In the 2-d treatments, the macronutrient elements $(\mathrm{K}, \mathrm{Na}, \mathrm{Ca}$ and $\mathrm{Mg}$ ) in both roots (Figure 2A) and shoots (Figure 2B) of treated rice seedlings was significantly lower than non-treated plants $(p<0.05)$ at higher than or equal to $8.0 \mathrm{mg} \mathrm{Cr} / \mathrm{L}$ in comparison to control, while slight 
Effects of trivalent chromium on biomass growth, water use efficiency and distribution of nutrient elements in rice seedlings

Table 4. Measured total Cr accumulated and BCF values in different plant materials of rice seedlings.

\begin{tabular}{|c|c|c|c|c|c|c|c|c|c|c|}
\hline \multirow[b]{2}{*}{$\begin{array}{c}\text { Conc. } \\
\text { (mg Cr/L) }\end{array}$} & \multicolumn{5}{|c|}{ 48-hr } & \multicolumn{5}{|c|}{ 96-hr } \\
\hline & $\begin{array}{l}\text { Cr in roots } \\
(\mu \mathrm{g} / \mathrm{g} D W)\end{array}$ & $\begin{array}{c}\text { Cr in shoots } \\
(\mu \mathrm{g} / \mathrm{g} D W)\end{array}$ & $\begin{array}{c}\text { Total } \\
\text { accumulation rate } \\
(\mu \mathrm{g} / \mathrm{g} \text { DW.d) }\end{array}$ & $\begin{array}{l}\text { BCF in } \\
\text { roots }\end{array}$ & $\begin{array}{l}\text { BCF in } \\
\text { shoots }\end{array}$ & $\begin{array}{l}\text { Cr in roots } \\
(\mu \mathrm{g} / \mathrm{g} D W)\end{array}$ & $\begin{array}{l}\text { Cr in shoots } \\
(\mu \mathrm{g} / \mathrm{g} D W)\end{array}$ & $\begin{array}{c}\text { Total } \\
\text { accumulation rate } \\
(\mu \mathrm{g} / \mathrm{g} \text { DW.d) }\end{array}$ & $\begin{array}{l}\text { BCF in } \\
\text { roots }\end{array}$ & $\begin{array}{l}\text { BCF in } \\
\text { shoots }\end{array}$ \\
\hline 2.0 & $\begin{array}{c}338.93 \\
(63.39)\end{array}$ & $\begin{array}{c}45.76 \\
(11.09)\end{array}$ & $\begin{array}{l}106.70 \\
(18.66)\end{array}$ & $\begin{array}{l}169.47 \\
(31.70)\end{array}$ & $\begin{array}{l}22.89 \\
(5.55)\end{array}$ & $\begin{array}{l}534.22 \\
(65.88)\end{array}$ & $\begin{array}{l}56.35 \\
(7.31)\end{array}$ & $\begin{array}{l}75.98 \\
(9.17)\end{array}$ & $\begin{array}{l}267.11 \\
(32.94)\end{array}$ & $\begin{array}{l}28.18 \\
(3.66)\end{array}$ \\
\hline 4.0 & $\begin{array}{c}651.57 \\
(139.18)\end{array}$ & $\begin{array}{c}61.18 \\
(13.31)\end{array}$ & $\begin{array}{l}197.74 \\
(40.74)\end{array}$ & $\begin{array}{l}162.89 \\
(34.79)\end{array}$ & $\begin{array}{l}14.76 \\
(2.92)\end{array}$ & $\begin{array}{l}1072.62 \\
(131.70)\end{array}$ & $\begin{array}{c}92.49 \\
(15.75)\end{array}$ & $\begin{array}{l}129.18 \\
(24.84)\end{array}$ & $\begin{array}{c}256.46 \\
(16.22)\end{array}$ & $\begin{array}{l}23.13 \\
(3.93)\end{array}$ \\
\hline 8.0 & $\begin{array}{l}1271.64 \\
(153.84)\end{array}$ & $\begin{array}{c}88.52 \\
(18.96)\end{array}$ & $\begin{array}{l}377.89 \\
(38.76)\end{array}$ & $\begin{array}{l}158.96 \\
(19.23)\end{array}$ & $\begin{array}{c}9.76 \\
(3.24)\end{array}$ & $\begin{array}{l}1781.38 \\
(219.90)\end{array}$ & $\begin{array}{l}150.31 \\
(24.32)\end{array}$ & $\begin{array}{l}259.13 \\
(29.01)\end{array}$ & $\begin{array}{l}228.02 \\
(24.85)\end{array}$ & $\begin{array}{l}18.79 \\
(3.04)\end{array}$ \\
\hline 16.0 & $\begin{array}{l}1456.39 \\
(225.40)\end{array}$ & $\begin{array}{l}189.16 \\
(53.32)\end{array}$ & $\begin{array}{l}439.60 \\
(23.85)\end{array}$ & $\begin{array}{c}91.03 \\
(14.09)\end{array}$ & $\begin{array}{c}9.67 \\
(1.87)\end{array}$ & $\begin{array}{c}2464.98 \\
(104.94)\end{array}$ & $\begin{array}{c}246.98 \\
(32.99)\end{array}$ & $\begin{array}{l}362.76 \\
(25.96)\end{array}$ & $\begin{array}{l}167.77 \\
(27.93)\end{array}$ & $\begin{array}{l}18.05 \\
(1.68)\end{array}$ \\
\hline 24.0 & $\begin{array}{l}1773.53 \\
(153.75)\end{array}$ & $\begin{array}{l}231.94 \\
(67.16)\end{array}$ & $\begin{array}{l}549.67 \\
(57.01)\end{array}$ & $\begin{array}{c}81.10 \\
(15.32)\end{array}$ & $\begin{array}{c}8.97 \\
(2.22)\end{array}$ & $\begin{array}{l}4016.15 \\
(328.52)\end{array}$ & $\begin{array}{l}319.30 \\
(48.51)\end{array}$ & $\begin{array}{l}462.82 \\
(31.49)\end{array}$ & $\begin{array}{r}139.05 \\
(9.25)\end{array}$ & $\begin{array}{l}14.94 \\
(0.50)\end{array}$ \\
\hline 32.0 & $\begin{array}{l}1858.87 \\
(381.62)\end{array}$ & $\begin{array}{l}235.81 \\
(90.14)\end{array}$ & $\begin{array}{l}553.49 \\
(17.46)\end{array}$ & $\begin{array}{c}51.19 \\
(16.44)\end{array}$ & $\begin{array}{c}7.37 \\
(2.82)\end{array}$ & $\begin{array}{c}2635.22 \\
(275.73)\end{array}$ & $\begin{array}{l}269.16 \\
(41.66)\end{array}$ & $\begin{array}{l}358.31 \\
(20.68)\end{array}$ & $\begin{array}{c}74.15 \\
(17.84)\end{array}$ & $\begin{array}{c}8.41 \\
(0.95)\end{array}$ \\
\hline 40.0 & $\begin{array}{l}1816.17 \\
(143.62)\end{array}$ & $\begin{array}{l}230.19 \\
(42.61)\end{array}$ & $\begin{array}{l}570.08 \\
(41.37)\end{array}$ & $\begin{array}{l}45.40 \\
(3.59)\end{array}$ & $\begin{array}{c}5.75 \\
(1.07)\end{array}$ & $\begin{array}{c}2498.63 \\
(346.77)\end{array}$ & $\begin{array}{l}263.83 \\
(54.45)\end{array}$ & $\begin{array}{l}361.58 \\
(52.31)\end{array}$ & $\begin{array}{l}62.47 \\
(6.17)\end{array}$ & $\begin{array}{c}7.20 \\
(1.02)\end{array}$ \\
\hline
\end{tabular}

Values are mean of 4 independent biological replicates. Numerical values in brackets represent standard deviation.
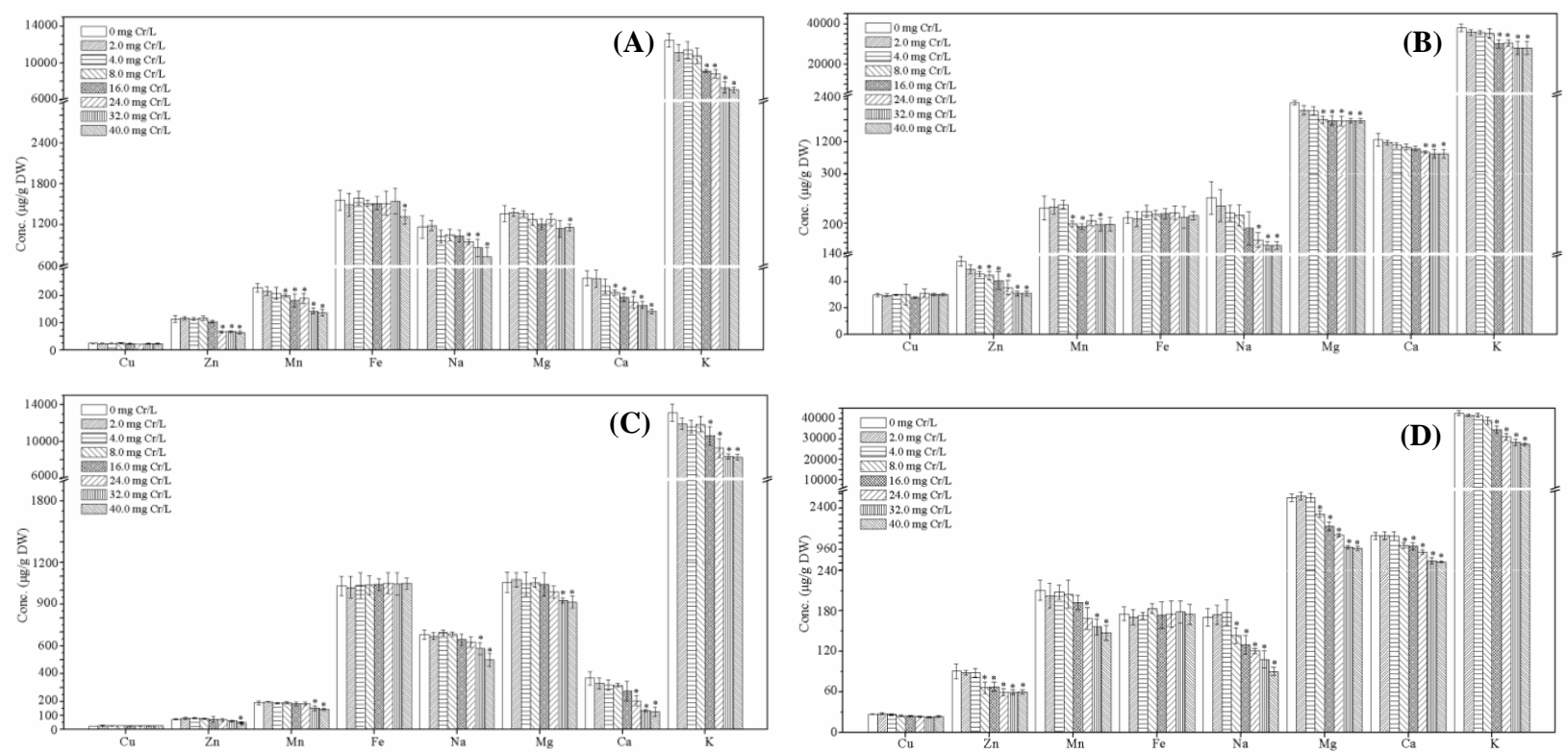

Figure 2. Content of different nutrient elements in plant materials of rice seedlings exposed to Cr(III). (A) Root and (B) shoot: 2-d; (C) Root and (D) shoot: 4-d; the values are mean of 4 individual replicates \pm SDs (in brackets). Asterisk symbol refers to significant difference between the treatment and control $(p<0.05)$.

difference between treatments and control $(p>0.05)$ was observed below $8.0 \mathrm{mg} \mathrm{Cr} / \mathrm{L}$. It was remarkable that, in both control and Cr-treated rice seedlings, shoots accumulated more macronutrient elements, except for $\mathrm{Na}$, than roots $(p<0.05)$. However, a different pattern was detected in the distribution of micronutrient elements. The application of $\mathrm{Cr}$ (III) showed a negligible effect on $\mathrm{Cu}$ accumulation in both roots and shoots ( $p>0.05$ ). Higher concentrations of $\mathrm{Cr}(\mathrm{III})$ cau- sed severe effects on distribution of other micronutrient elements (Fe, Mn and Zn) $(p<0.05)$.

Similar accumulation patterns of macronutrient elements were observed in both roots (Figure 2C) and shoots (Figure 2D) of rice seedlings in the 4-d treatments. No detectable effects was found on the content of $\mathrm{K}, \mathrm{Na}$, Ca and $\mathrm{Mg}$ at lower concentrations of $\mathrm{Cr}(\mathrm{III})$ ( $p>0.05$ ), while higher concentrations of $\mathrm{Cr}(\mathrm{III})$ caused significant decreases in these elements in both 
roots and shoots in comparison to control $(p<0.05)$.

\section{Discussion and Conclusion}

Inhibition of seed germination and root development, leaf-chlorosis, and stunted biomass production are the most common phytotoxic symptoms due to biotic and/or abiotic stresses ${ }^{[13,17]}$. In this work, neither negative growth in biomass nor visible toxic symptoms of chlorosis was observed in any of the Cr(III) treatments. However, a remarkable decreased trend in RGR and WUE of rice seedlings was detected with increasing $\mathrm{Cr}(\mathrm{III})$ concentrations. We also noted that both parameters showed differently responsive to $\mathrm{Cr}$ (III) exposure, in which RGR of rice seedlings was more sensitive to Cr change than WUE, judged by the lower ECs values. A similar conclusion was also reached in our previous work, where a lower ECs values for rice seedlings exposed to Cd was obtained using RGR as sensitive variables in comparison to $\mathrm{WUE}^{[13]}$.

The bioconcentration factor (BCF) is defined as the ratio of metal concentration in the biomass to the initial concentration of metal ions in the feed solution ${ }^{[18]}$. The estimation of BCF values from roots and shoots of rice seedlings exposed to $\mathrm{Cr}$ (III) are shown in Table 4 , in which significantly higher BCF values in roots than in shoots were obtained $(p<0.05)$ in both testing series, indicating that the translocation of $\mathrm{Cr}$ within plant materials was most likely to occur, but roots rather than shoots were major sites for $\mathrm{Cr}$ accumulation. It was evident that rice seedlings were able to take up more $\mathrm{Cr}$ from the hydroponic solution after exposing rice to $\mathrm{Cr}$ (III) for $4 \mathrm{~d}$. Indeed, the BCF values in both roots and shoots at the 4-d treatment were always higher than these at the $2-\mathrm{d}$ treatment $(p<0.05)$. Here, interests have been generated to compare the translocation potential between the two testing series using the ratio of $\mathrm{BCF}_{\text {root }}$ to $\mathrm{BCF}_{\text {shoot }}$ at the respective treatment concentrations. This outcome of the comparison was quite surprising: a very similar ratio was obtained in both treatments, where the mean values were determined to be 9.72 (SD 3.21) and 9.83 (SD 1.29) for 2-d and 4-d treatments, respectively, suggesting that the translocation capacity of $\mathrm{Cr}$ from roots to shoots was independent on the exposure period.

It is evident that excess of heavy metals usually affects mineral nutrient homeostasis, which results from the effects on availability, absorption and transport of nutrients within plants ${ }^{[11,19]}$. Indeed, uptake and distribution of nutrient elements was variable in rice seedlings exposed to $\mathrm{Cr}(\mathrm{III})$, most likely due to their different roles in plant growth, development and yield $^{[11]}$. For instance, $\mathrm{K}$ is an important enzyme activator involved in synthesis of protein and sugar, and also functions in osmotic modulation in plants ${ }^{[20]}$. In this current work, a significant difference in K content in both roots and shoots was observed in rice seedlings to $\mathrm{Cr}(\mathrm{III})$ at concentrations of $8.0 \mathrm{mg} \mathrm{Cr} / \mathrm{L}$ onwards in respect to control. This is constant to the results obtained from estimation of RGR and WUE. Mg is a key component of chlorophyll, and $\mathrm{Cu}, \mathrm{Fe}$ and $\mathrm{Mn}$ play a vital role in synthesis or stability of chlorophyll $^{[21]}$. However, uptake and distribution of these nutrient elements was completely different in this work. Negligible effects on $\mathrm{Mg}$, Fe and $\mathrm{Cu}$ were observed, while the application of Cr(III) showed significantly impact on distribution of Mn, suggesting that Cr(III) may carry more weight on the effect on uptake and distribution of $\mathrm{Mn}$ rather than $\mathrm{Cu}, \mathrm{Fe}$ and $\mathrm{Mg}$. Additionally, $\mathrm{Zn}$ is the only metal represented in several electron transport enzymes ${ }^{[22]}$. In general, higher doses of $\mathrm{Cr}$ (III) had severe effects on uptake and distribution of $\mathrm{Zn}$ in both roots and shoots.

In summary, phytotoxicity of $\mathrm{Cr}$ (III) to young rice seedlings was evident, judged by negative responses of both RGR and WUE to Cr exposure. Results from EC estimation indicated that the former was more susceptible to the changes of $\mathrm{Cr}$ (III) than the latter. Although rice seedlings were able to take up $\operatorname{Cr}($ III) efficiently, translocation of $\mathrm{Cr}$ within plant materials was a restricted process. Additionally, the effect of $\mathrm{Cr}$ (III) application on uptake and distribution of nutrient elements was variable.

\section{Author Contributions}

Xing-Hui Feng performed the experiments and collected data. Xiao-Zhang Yu conceived the study, conducted data analysis and drafted the manuscript. All authors read and approved the final manuscript.

\section{Conflict of Interest and Funding}

The authors declare no conflict of interest. This work was financially supported by the research foundations from Guilin University of Technology (Grant No. GUTRC2011007) and The Guangxi Talent Highland for Hazardous Waste Disposal Industrialization.

\section{References}

1. Wong S C, Li X D, Zhang G, et al. 2002, Heavy metals in agricultural soils of the Pearl River Delta, South Chi- 
na. Environmental Pollution, vol.119(1): 33-44. http://dx.doi.org/10.1016/S0269-7491(01)00325-6.

2. Han F X, Banin A, Su Y, et al. 2002, Industrial age anthropogenic inputs of heavy metals into the pedosphere. Die Naturwissenschaften, vol.89(11): 497-504. http://dx.doi.org/10.1007/s00114-002-0373-4.

3. Zeng F, Zhao F, Qiu B, et al. 2011, Alleviation of chromium toxicity by silicon addition in rice plants. Agricultural Sciences in China, vol.10(8): 1188-1196. http://dx.doi.org/10.1016/S1671-2927(11)60109-0.

4. Zayed A M and Terry N, 2003. Chromium in the environment: factors affecting biological remediation. Plant and Soil, vol.249(1): 139-156. http://dx.doi.org/10.1023/A:1022504826342.

5. Dixit V, Pandey V and Shyam R, 2002, Chromium ions inactivate electron transport and enhance superoxide generation in vivo in pea (Pisum sativum L.cv. Azad) root mitochondria. Plant Cell and Environment, vol.25(5): 687-693. http://dx.doi.org/10.1046/j.1365-3040.2002.00843.x.

6. Yu X Z and Gu J-D, 2007, Accumulation and distribution of trivalent chromium and effects on hybrid willow (salix matsudana koidz x alba l.) metabolism. Archives of Environmental Contamination and Toxicology, vol.52(4): 503-511.

http://dx.doi.org/10.1007/s00244-006-0155-7.

7. Shanker A K, Cervantes C, Loza-Tavera H, et al. 2005, Chromium toxicity in plants. Environment International, vol.31(5): 739-753.

http://dx.doi.org/10.1016/j.envint.2005.02.003.

8. Panda S K, 2007, Chromium-mediated oxidative stress and ultrastructural changes in root cells of developing rice seedlings. Journal of Plant Physiology, vol.164(11): 1419-1428.

http://dx.doi.org/10.1016/j.jplph.2007.01.012.

9. Yu H, Wang J L, Fang W, et al. 2006. Cadmium accumulation in different rice cultivars and screening for pollution-safe cultivars of rice. The Science of the Total Environment, vol.370(2-3): 302-309.

http://dx.doi.org/10.1016/j.scitotenv.2006.06.013.

10. Ebbs S D, Piccinin R C, Goodger J Q D, et al. 2008, Transport of ferrocyanide by two eucalypt species and sorghum. International Journal of Phytoremediation, vol.10: 343-357. http://dx.doi.org/10.1080/15226510802096242.

11. Yu X Z and Zhang F Z, 2013, Effects of exogenous thiocyanate on mineral nutrients, antioxidative responses and free amino acids in rice seedlings. Ecotoxicology, vol.22: 752-760.

http://dx.doi.org/10.1007/s10646-013-1069-6.
12. Banks M K, Schwab A P and Henderson C, 2006, Leaching and reduction of chromium in soil as affected by soil organic content and plants. Chemosphere, vol.62(2): 255-264.

http://dx.doi.org/10.1016/j.chemosphere.2005.05.020.

13. Zhang X H, Yu X Z and Liang Y P, 2014, Parameter determination involved in phytotoxicity and transport of cadmium in rice seedlings. International Biodeterioriation \& Biodegration, vol.96: 121-126.

http://dx.doi.org/10.1016/j.ibiod.2014.09.009.

14. Trapp S, Zambrano K C, Kusk K O, et al, 2000, A phytotoxicity test using transpiration of willows. Archives of Environmental Contamination and Toxicology, vol.39: 154-160. http://dx.doi.org/10.1007/s002440010091.

15. Zhu Y L, Zyaed A M, Qian J H, et al. 1999, Phytoaccumulation of trace elements by wetland plants: II. Water hyacinth. Journal of Environmental Quality, vol.28(1): 339-344.

http://dx.doi.org/10.2134/jeq1999.00472425002800010 042x.

16. Yu X Z, Trapp S, Zhou P H, et al. 2006, Response of weeping willows to linear alkylbenzene sulfonate. Chemosphere, vol.64: 43-48. http://dx.doi.org/10.1016/j.chemosphere.2005.11.025.

17. Achery V M M, Jena S, Panda K K, et al. 2008, Aluminum induced oxidative stress and DNA damage in root cells of Allium cepa L. Ecotoxicology and Environment Safety, vol.70(2): 300-310.

http://dx.doi.org/10.1016/j.ecoenv.2007.10.022.

18. Raskin I, Kumar P B A N, Dushenkov S, et al.1994, Bioconcentration of heavy metals by plants. Current Opinion in Biotechnology, vol.5(3): 285-290. http://dx.doi.org/10.1016/0958-1669(94)90030-2.

19. Ali N A, Bernal M P and Ater M, 2002, Tolerance and bioaccumulation of copper in Phragmites australis and Zea mays. Plant and Soil, vol.239(1): 103-111. http://dx.doi.org/10.1023/A:1014995321560.

20. Rai V K, 2002, Role of amino acids in plant responses to stresses. Biologia Plantarum, vol.45(4): 481-487. http://dx.doi.org/10.1023/A:1022308229759.

21. Wang C, Zhang S H, Wang P F, et al. 2009, The effect of excess $\mathrm{Zn}$ on mineral nutrition and antioxidative response in rapeseed seedlings. Chemosphere, vol.75(11): 1469-1476.

http://dx.doi.org/10.1016/j.chemosphere.2009.02.033.

22. Broadley M R, White P J, Hammond J P, et al. 2007, Zinc in plants. The New Phytologist, vol.173(4): 677-702. http://dx.doi.org/10.1011/j.1469-8137.2007.01996.x. 